\title{
Historical Development of Science and Technical Education in India
}

\author{
Priya Gupta \\ Asst Prof at KMRD Jain College, \\ Malerkotla (Punjab, India) \\ Hno. 648 I, BRS Nagar, \\ Ludhiana (Punjab, India)
}

\begin{abstract}
Planning of future not only needs not only to make a critical study of the past, but also to analyze the general psyche of the people responsible for formulating development policies, to understand the complexities of the development process and to identify the factors responsible for achievements and failures.
\end{abstract}

The main objective of this paper is to examine the roots of scientific and technical education in India. I have tried to include all the minute details of the various strategies followed in the past which leads to the birth of scientific and technical education in India.

\section{General Terms}

History of technical education, Emergence of scientific education, roots of technical education in India

\section{Keywords}

Technical education, Vedas, Gurukulas, Britishers, military engineers, epics, post-war transition, history of technical education, technical education in India

\section{INTRODUCTION}

If one studies the development process in totality and in historical perspective, it may not be difficult to establish beyond doubt that the roots of modern scientific and technical education can be traced to Vedic period (prior to $1000 \mathrm{BC})$ and the Epic period (1000 BC to $800 \mathrm{BC}$ ) which comprised ashrams(hermitages) of acharyas and kulagurus (teacher sages). It is believed that those teachings included technological skills and science of warfare besides Vedas, languages, logic, philosophy, ethics, politics and economics. The education system of the Epic period evolved into three types of institutions: gurukulas, temple schools and the agrahara village institutions.An institution of great fame, Taxila developed in the north-west India (now in Pakistan). With the political influence of Hindus, Persians, Greeks, Taxila served as the capital of number dominions and through exposure of many cultural influences, acquired a cosmopolitan character. Students came from far off places to study various arts and sciences and medicine. Numerous technical skills such as carpentry, smithy, foundry and weaving were taught at Taxila

In India, the Buddhist developed university institutions similar to stadium generale several centuries before their appearance in Europe. Among the famous institutions are Nalanda, Vikramshila, Jagaddala and Ranchi which gradually disintegrated with the decay of Buddhism in India.
Specifically details of technical and vocational education in medieval India are not available. However, there is ample evidence that vocational skills were highly developed. Elegance and excellence of articles such as fine fabrics of cotton and silk, embroidery, painted and enameled wares, swords and knives and gold and silver jewellery are well known. Such high quality could not have been achieved and sustained for centuries without a dependable system of technical education.

\section{EARLY DEVELOPMENTS DURING THE BRITISH RULE}

If we examine the historical development of technical education, it will be discovered that the foundation of technical education in India was laid almost at the same time as in Europe but its growth in India was very restrictive and slow till India became Independent. Soon, after the battle of Plessey in 1754, the status of presence of Britishers was changed from traders to colonizers. Therefore, to rule the country, it was essential that they should have an intimate knowledge of the country's topography through physical survey of the land. For achieving this object, the English traders established a survey school in Madras (Chennai) in 1794 to train Indian personnel in land survey to assist British Surveyors.Later on, technical education spread to other parts of the country. The Madras Survey School trained only English boys. The 'native Indians' were left out because of political and military implications of survey work. The East India Company feared that survey maps could fall into the hands of their French and Dutch rivals. Civil surveying was a well-established branch of knowledge in India as it served revenue purposes. Land revenue maps were in vogue much before the British came in.

The General Committee of Public Instruction formed in 1823 , comprising British Officers was the only organ to advise the Government on educational matters. This committee was replaced by the Council of Education and the subject of education in general was brought directly under the control of the government. The General Committee and later the Council of Education advised the branches of study useful to students for their livelihood. Apart from reading, writing and arithmetic, surveying was strongly emphasized on account of its utility to the British rule. The concept gradually emerged in Bengal that drawing and surveying can be taught at only college level and not at school level.

From the need to have these subject taught in colleges to the desirability of Colleges of Civil Engineering was a big step, yet quite logical. Engineering was yet not classified into several disciplines; the term meant engineering for 
civil purposes as distinct from military functions. The importance of civil engineering as a discipline of education for Indians started receiving emphasis in $1804 \mathrm{~s}$ with road and canal projects as goals.

So, it is worth mentioning that the British started first the technical education program in India with training to overseers on construction of roads, bridges, buildings, railways, canals, and docks, etc. Simultaneously, lower grade technicians were also trained in the use of measuring and survey equipments needed for army, navy and other technical establishment for maintenance of a colony of the British crown. The instructors for those training schools were mostly British except the lower grade instructors like craftsman and artisans from local population. We can say that the growth and development of formal technical education in India has come a long way since its inception in the 19thcentury under British rule. It expanded multifold after India attained its Independence and it is still progressing.

\section{ROLE OF MILITARY ENGINEERS IN ENGINEERING EDUCATION}

The Royal Engineers in the Army in India played a major role in influencing, the fortune of Rorkee College and the three other colleges in Kolkata, Mumbai and Chennai. Military engineers were the only type of engineers that came to India with the East India Company. As the Company assumed greater power for governing the country, all technical jobs in engineering and science were entrusted to military engineers. Almost all the PWD officers came from this tribe and engineering education came under their purview. The principals and teachers of these colleges were also army engineers. These men ensured that military was the feeder for admission to these colleges and the colleges in turn served the army by running special courses for its officers and other ranks. The impulse for creation of centers of technical training came from the British Raj rulers of India. While Superintending Engineers were mostly recruited from Britain, lower grades e.g. Craftsmen, Artisans and sub-overseers who were recruited locally. The necessity to make them more efficient, led to the establishment of industrial schools attached to Indian Ordnance Factories and other engineering establishments.

The first engineering college was established in the Uttar Pradesh in 1847 for the training of Civil Engineers at Roorkee, Thomason College (which later become IIT Roorkee) which made use of the large workshops and public buildings there that were erected for the Upper Ganges Canal.

In pursuance of the Government policy, three Engineering Colleges were opened by about 1856 in the three Presidencies. In Bengal Presidency, a College called the Calcutta College of Civil Engineering (which later became Indian Institute of Engineering Science and Technology, Shibpur) was opened at the Writers' Building in November 1856. In Bombay Presidency, the Overseers' School at Pune eventually became the College of Engineering, Pune and was affiliated to the Bombay University in 1858. In the Madras Presidency, the industrial school attached to the Gun Carriage Factory became ultimately the College of Engineering, Guindy and affiliated to the Madras University (1858).
Table1. Year wise establishment of various institutions in early times

\begin{tabular}{|c|c|}
\hline Year & Institution \\
\hline 1842 & $\begin{array}{l}\text { James Thomson proposed the establishment } \\
\text { of College of Civil Engineering at Rorkee. }\end{array}$ \\
\hline 1854 & $\begin{array}{l}\text { a school for the training of overseers was } \\
\text { established in Pune. 'Poona Engineering } \\
\text { Class and Mechanical School' to train } \\
\text { subordinate officers for carrying out public } \\
\text { works like buildings, dams, canals, railways } \\
\text { and bridges. }\end{array}$ \\
\hline 1856 & $\begin{array}{l}\text { A college called the Calcutta College of } \\
\text { Civil Engineering was opened at the } \\
\text { Writers' building. The name was changed to } \\
\text { Bengal Engineering College in } 1857 \text {. }\end{array}$ \\
\hline 1866 & $\begin{array}{l}\text { College of Engineering, Poona got affiliated } \\
\text { to the Bombay University. The educational } \\
\text { work in these colleges of Guigy (Now } \\
\text { Guindy), Sibpur and Poona licentiated } \\
\text { courses in Civil Engineering in } 1880 \text {. }\end{array}$ \\
\hline 1887 & $\begin{array}{l}\text { the Victoria Jubilee Technical institute was } \\
\text { established in Bombay (Now Mumbai) to } \\
\text { commemorate the diamond Jubilee of } \\
\text { Queen Victoria Reign. The main objective } \\
\text { of V.J.T.I. was to train licentiates in } \\
\text { electrical, mechanical and textile } \\
\text { engineering and technology. }\end{array}$ \\
\hline 1906 & $\begin{array}{l}\text { The first twentieth century College of } \\
\text { Engineering and Technology was } \\
\text { established at Jadavpur in Bengal by the } \\
\text { National Council of Education. }\end{array}$ \\
\hline 1911 & $\begin{array}{l}\text { Sir Jamshed Tata established the Indian } \\
\text { Institute of } \\
\text { Science at Banglore. }\end{array}$ \\
\hline 1913 & $\begin{array}{l}\text { Government Resolution on Educational } \\
\text { Policy made recommendations for inclusion } \\
\text { of subjects of industrial importance in the } \\
\text { curriculum. Hartog Committee (1928- } \\
\text { 29) suggested the diversion of more boys to } \\
\text { industrial and Commercialcareers at the end } \\
\text { of middle stage, for which provision should } \\
\text { be made by alternative course in that stage }\end{array}$ \\
\hline 1915 & $\begin{array}{l}\text { The Indian Institute of Science, Bangalore, } \\
\text { opened Electrical } \\
\text { Engineering classes under Dr. Alfred Hay, } \\
\text { and began to give certificates and } \\
\text { associateships, the latter being regarded } \\
\text { equivalent to a degree }\end{array}$ \\
\hline 1916 & Banaras HinduUniversity was established. \\
\hline 1917 & $\begin{array}{l}\text { Calcutta University Commission debated } \\
\text { the pros and cons for introduction of degree } \\
\text { courses in mechanical and electrical } \\
\text { engineering }\end{array}$ \\
\hline 1919 & $\begin{array}{l}\text { Pt. Madan Mohan Malviya established } \\
\text { College of Banaras which introduced degree }\end{array}$ \\
\hline
\end{tabular}




\begin{tabular}{|l|l|}
\hline & $\begin{array}{l}\text { classes in mechanical, electrical engineering } \\
\text { and metallurgy }\end{array}$ \\
\hline 1920 & HarcourtButler Technological Institute was \\
\hline $1921-1937$ & $\begin{array}{l}\text { a number ofsuch institutions were set up } \\
\text { e.g., The Indian } \\
\text { School of Mines, Dhanbad; The Harcourt } \\
\text { Technological Institute, Kanpur; and } \\
\text { TheSchool of Chemical Technology, } \\
\text { Bombay }\end{array}$ \\
\hline $1931-1940$ & $\begin{array}{l}\text { different colleges named Bengal } \\
\text { Engineering College, } \\
\text { Sibpur, Guindy and Poona started } \\
\text { mechanical, electrical and metallurgy } \\
\text { courses. }\end{array}$ \\
\hline 1948 & $\begin{array}{l}\text { The Roorkee University Act was passed and } \\
\text { in 1949, the status of this college was } \\
\text { further enhanced and the Roorkee } \\
\text { Engineering College became first Technical } \\
\text { University of India. }\end{array}$ \\
\hline
\end{tabular}

\section{THE POST WAR TRANSITION}

The Post-War Transition: As the World War II drew to its end, the British Government realized that the era of colonialism was over. A transfer of power to Indian hands became inevitable. The British Government of India, therefore, considered it futile to hold on to its economic and industrial policies to suit the interest of British industry. During the dusk years of its rule,the British Raj decided to release the brakes it had applied for a century to withhold industrial progress. One of the steps was the thinking of technical education in a big way to provide facilities all over India for higher education in science, engineering and technology comparable to anywhere in the world. The overseas scholarship scheme of 1944 was pursued more vigorously. The Central Advisory Board of Education (CABE) was asked to prepare a report on the post-war educational development in India.

In the light of this report, an ad-hoc committee under the chairmanship of N.R. Sarkar was constituted in 1945 to advice on the provision of advanced technical education in India.

The Sarkar Committee recommended the establishment of at least four Higher Technical Institutes one in each zone -north, south, east and west. A crucial recommendation of $\mathrm{CABE}$ was the constitution of a central agency to ensure an all- India coordinated and integrated growth and spread of technical education. The Government of India, thus, established the All India Council for Technical Education (AICTE) to supervise all technical education above the high school stage. The Council had its inaugural meeting under the Chairmanship of Sarkar in May 1946.

\section{EARLY DEVELOPMENTS IN INDEPENDENT INDIA}

In pursuance of the Sarkar Committee recommendations, five Indian Institutes of Technology were gradually established between 1950 and 1961. The Government of India appointed a Commission under the chairmanship of S. Radhakrishnan to examine the Indian University education -- including technical education -- and to suggest improvements and extensions. The Commission in its report emphasized the need of new types of engineering and technical institutions in India to produce men not only skilled in technology but who were well integrated individuals. It was emphasized that technical education must include elements of general education and engineering courses should have underlying scientific studies. The Commission also advocated closer liaison between engineering colleges and universities so that the colleges would grow vigorously in an atmosphere of higher research in science. Wherever possible, the existing engineering and technical colleges should be upgraded for postgraduate training and research. The Commission further recommended starting, without delay, higher technological institutes to produce much needed engineerscientists and design and development engineers. The Commission clearly advocated that engineering colleges be not controlled or dominated in their administration by the Government. These and other recommendations led to several developments in the succeeding years. The first year of all undergraduate degree courses were made common in all branches of engineering. Curricula were revised to include general education and basic physical and engineering sciences.

\subsection{The System of Governance of TechnicalEducation}

Education is a concurrent subject underthe purview of the Central Government as well asthe State Government. In addition, statutory bodieslike (AICTE) and the University Grants Commission (UGC) have their empowerment by the Acts ofParliament to regulate higher education. ProfessionalBodies such as the Council of Architecture,Pharmacy Council of India and the Institution ofEngineers(India) have their roles, some of whichare well defined and some others not so. Theuniversities and deemed-to-be universities exercisevarious controls arising out of their statutes.The Bureau of Technical Education (BTE) in theMinistry of Human Resource Developmentprovides grants to centrally funded institutions suchas the Indian Institutes of Technology (IITs), IndianInstitutes of Management (IIMs), School of Planningand Architecture (SPA), New Delhi, TechnicalTeachers Training Institutes (TTTIs), Indian School of Mines (ISM), Dhanbad, and Indian Institutes ofInformation Technology (IIITs). BTE processes the programmers of these centrally funded Institutions, monitors and evaluates them.

UGC allocates anddisburses funds to the central universities and hasthe mandate with reference to norms and standardsof education in the universities.

AICTE was originally constituted as an advisorybody in 1945 for all matters relating to technical education. Although AICTE had no statutory power,it played an important role in the development oftechnical education in India. In the late nineteenfifties, early sixties and eighties there was a largescaleexpansion of technical education. Whereas theearlier growth occurred with the approval of AICTEand the Government of India, the expansion ofeighties was brought about primarily in the selffinancingsector without the approval of AICTE andthe Government of India, and was localized in fourStates Karnataka, Maharashtra, Andhra Pradeshand Tamil Nadu. It was in this period that theNational Policy on Education (NEP) (1986) envisagedthat AICTE be made a statutory body and be vestedwith the authority for planning, 
formulation, andmaintenance of norms and standards. Even as earlyas 1964, the Education Commission under the chairmanshipof D. S. Kothari had made similar recommendationfor proper administration of technicaleducation. AICTE was made a statutory body in1987, by an act of Parliament, for appropriateplanning and coordinated development of thetechnical education system throughout the country.AICTE functions through its various statutory bodiesto comply with the mandate provided by the Act.The Post-War Transition: As the World War II drew toits end, the British Government realized that the eraof colonialism was over. A transfer of power to Indianhands became inevitable. The British Government ofIndia, therefore, considered it futile to hold on to itseconomic and industrial policies to suit the interestof British industry. During the dusk years of its rule, the British Raj decided to release the brakes it hadapplied for a century to withhold industrial progress.

\section{NEED FOR A TECHNICAL EDUCATION POLICY}

The National Education Policy (NEP) of 1986 addressed to the issues of engineering and technical education in the private sector in a different sector in a different context. The 1980s saw a phenomenal growth of technical institutions in four states. This sudden increase of technical education, like in adiabatic expansion of a thermodynamic process, resulted in cooling of quality. To arrest the decline in the degree of excellence, as envisaged in NEP, AICTE was made a statutory authority. This response was largely conditioned by the imperatives of damage control rather than the need of control to ensure high norms and standards. Through the years, AICTE has become more effective in fulfilling its mandate flowing from the AICTE Act of 1987. The Act was born in a milieu of the distrust of the private sector in the area of technical education. The existing system is a mix of what was designed and what has evolved, both of which needs a critical appraisal and review.

\section{CONCLUSION}

A new policy initiative is needed which would take into account the inescapable role of the private sector, the emerging technologies, the new modes of knowledge delivery in an electric environment, the role of Governments and universities, the system of regulations and controls, the market pressure of foreign agencies which are making inroads in the Indian education system, networking of education and research, distance education, the system of accreditation and its international interface and the promotion of excellence and its sustenance.

India urgently needs a coordinated blueprint for technical education, research and development encompassing Governments, private sectors, and research and academic institutions, consistent with industrial, technological and economic future of the country.

\section{REFERENCES}

[1] Ahmed, T. and Satija ,M.P.(2005) Growth of technical education at degree level in Punjab : A historical perspective. The Indian Journal of Technical Education. Vol.28(3).pp.81-91.

[2] www.mrdowling.com

[3] Sen,Biman.(1989). Technical education in India192180. In Studies in educational reforms in India. P.R.Panchmukhi.Ed.vol 3 part-2.Bombay, Himalya.p.189.

[4] Awale, S.D.(1996)Engineering teachers in the development of technical education system in India.ISTE, New Delhi.p.3.

[5] Awale, S.D.(1996). Some critical issues relating to engineering teachers in the development of technical education system in India. New Delhi, Indian Society for Technical Education ( ISTE).

[6] 2 Chanderkant, L.S.(1971). Polytechnical education in India. Bombay, D.B. Taraporewala, MacMillan publishers. p.26. 